\title{
COMMENT
}

\section{COLLECTION OF UNPAID WAGES AND FINANCIAL RESPONSIBILITY OF EMPLOYERS*}

\section{AIEx Erson $\dagger$}

7 HE problem of the collection of claims for wages past due has been long recognized. The statute books of many states, the statistics of labor commissioners and of legal aid societies bear evidence of the effort advanced to assist the unpaid laborer. Underlying this concern are certain facts-today almost truisms. Non-payment of wages results in dependency which, in turn, affects the economic welfare of the community; ordinary judicial process does not offer relief to the unpaid laborer. The action of the unscrupulous or improvident employer who refuses to pay wages justly due provokes for the employee all the problems of the unemployed worker. The worker, his faith in government and justice undermined, goes his way embittered against society.

How extensive is the problem today? The member agencies of the National Association of Legal Aid Organizations for the ten year period I924 to 1933 handled 309,556 wage claims. ${ }^{x}$ Assuming that the average claim was $\$ 40.00$ (the average claim in sixteen states reporting to the Bureau of Labor Statistics in I932 was $\$ 41.00),{ }^{2}$ the total amount of unpaid wages represented by these claims would be in excess of $\$ 12,300,000$. Legal Aid Societies today serve a territory in which some thirty-nine million people live. ${ }^{3}$ What of the wage claims of the unserved areas? If we turn to the activities of the labor departments for an answer to this question, we find that for 1932, twenty states reported 70,000 claims and the collection of approximately $\$ I, 450,000$. But this record is dimmed by the fact that of

* This article is a revision of a paper presented before the American Association for Labor Legislation at the National Conference of Social Work, held at Indianapolis, Indiana, on May 27, I937.

$\dagger$ Member of the Chicago Bar, Lecturer in Legal Relations, School of Social Service Administration, University of Chicago.

× Smith-Bradway, Growth of Legal Aid Work in the U.S., Bull. no. 607 U.S. Dept. of Labor, Bureau of Labor Statistics 67 .

2 Work of State Labor Offices in Behalf of Wage Claimants, 37 Monthly Labor Rev. Oct I933, 776 .

3 Smith-Bradway, op. cit. supra, anote I, at I2I. 
the sums collected $\$ 750,000$ was collected in California alone. New York with a wage-earning population far in excess of California reported the collection of slightly more than $\$ 200,000$; Massachusetts, about $\$ 50,000$. The remaining seventeen states accounted for only $\$ 450,000$. But in eighteen states labor offices reported no wage claims. ${ }^{4}$

The low amounts collected by the majority of reporting states and the large number of states indicating no wage claims, does not necessarily indicate that in these regions employers are more conscientious and that the problem therefore, does not exist. Rather it indicates that the problem of unpaid wages is not being adequately met. The record of California in contrast to the other states is the best proof of the fact. It is reasonable to believe that in large areas of this country today many unpaid wage earners look in vain for effective assistance.

Legislative attack upon the problem has been along four lines: first, there are statutes which attempt to adjust the judicial process to meet the special needs of wage earners. The expense and delay incident to court procedures is tempered with provisions waiving court costs for poor persons, providing that attorneys fees may be awarded as part of the judgment when wages are sued for, providing as penalty that wages continue for a specific period until paid, and setting up special small claims courts and conciliation tribunals. The second group of laws rely upon the penal sanction and provide for fine and imprisonment for fraudulent overreaching by an employer. A third group of laws, including the Federal Bankruptcy Act, look upon the financial irresponsibility of the employer as the kernel of the evil and protect the wage claim by making it a preferred claim in the case of the insolvency or receivership of the employer and by authorizing execution of a judgment for wage claims against property ordinarily exempt from execution. The fourth and most recent development is found in those laws, patterned after the California law, which seek a remedy first outside the judicial process. These laws specifically empower labor commissioners to settle wage claims. New Mexico, New York, Oregon, Nevada, Utah, Michigan, Washington, Illinois and South Carolina ${ }^{6}$ have joined this new move. In one group of states, oper-

${ }_{4}$ Work of State Labor Offices in Behalf of Wage Claimants, 37 Monthly Labor Rev. Oct. r933, 776-9.

5 Deering, Calif. General Laws, Act. 4743, 224I (r93I).

${ }^{6}$ New Mex. L. I931, c. 9, § 9; id. I937, c. I09; N.Y. L. I937, c. 500, par. I; Ore. L. I931, c. 287 , as amended by Ore. L. I933, c. $279,424-27$; Nev. Comp. L. I929, $\$ 275$, amended by Act of 1931 , c. 46; Utah Rev. Stat. r933, title 49, c. 9-a, 634; Utah L. x937, c. 6o; Mich. Pub. Acts 1935; no. 224; Wash. L. 1935, c. 96; Ill. L. 1937, 596; S.C.L. 1937, no. 643, Governor's Receipt Book for Acts (act not as yet approved). 
ating without legislative sanction, labor commissioners collect wage claims. In I932, according to the Bureau of Labor Statistics, these states collected a total of $\$ 68,000$ in unpaid wages.

We do not, as yet, have sufficient information upon which we can evaluate and compare the effectiveness of these various legislative approaches. In the actual prosecution of claims, statutes of the first type offer undoubted assistance. Many an employer in the experience of the writer has paid his debt rather than risk the increased penalty of paying the attorney's fees of the employee or of paying for labor not performed. Many an employee would have been unable to file suit, if compelled to pay costs in advance or attorney's fees. Likewise, there can be no question that the fear of criminal prosecution inhibits the unscrupulous or over-reaching employer. Wage claim preference in cases of insolvency or execution sale goes far to reduce the risk of the employee who works for an honest but financially unsound employer. The last method, that of putting the responsibility of coordinating all activities for collection of wage claims upon an administrative official has, as a result of the California experience, become accepted as the most effective legislative method of meeting the problem.

This fact was recognized in 1927 in the drafting of the model wage claim collection statute, which came about through the combined efforts of the Association of Governmental Labor officials, the National Association of Legal Aid Organizations and the Legal Aid Committee of the American Bar Association. All existing American legislation upon the subject was considered and the best features were brought together in this draft. ${ }^{7}$ The fundamental premise supporting the draft was expressed by the committee as follows:

"A good wage law must show so many effective teeth that its threat will be ever present to all whom it is meant to curb. Wage claimants as a class pitifully lack the means for enduring even a moderate amount of delay. That law helps them most which forestalls wrongs meditated but yet undone, not confining its effect to the correction of wrongs already done. And since some cases of correction must be encountered and quickly dealt with there is a double reason for giving the administrative agency more than one clear method of inflicting prompt, painful pressure on defaulting employers. The agency should have a set of thumbscrews so assorted as to fit every unfairly grasping hand."

The draft provides for prompt payment of wages, for posting of paydays and a summary of the act, for criminal punishment of an employer

${ }^{7} 52$ Amer. Bar Assn. Rep. 324 (I927).

${ }^{8} I d$. at 325 . 
who fraudulently refuses to pay for court costs or expenses to an employee, and places the responsibility for enforcement of the act upon the labor commissioner. The labor commissioner may attempt conciliation, may take assignment of wage claims and sue for the employee and may, as a last resort, invoke criminal penalties. Two unusual provisions are included. One, based upon a Colorado statute, enables the commissioner to institute proceedings to forfeit the charter of any corporation violating the act. By means of the second, the commissioner may, after entry of judgment against an employer under the act, require the execution of a bond conditioned upon future compliance with the act. Upon failure to give the bond the commissioner is authorized to apply to a court for an injunction to restrain the employer from doing business in the state.

Considerable study and effort followed the I927 report. In 1929 and I93 I the Illinois legislature passed bills incorporating most of the provisions of the suggested draft. These bills were vetoed by the Governor upon an opinion of the Attorney General of Illinois that they were unconstitutional. In 1937 a bill was finally enacted which met the approval of the executive. ${ }^{9}$ In 1935 , Michigan ${ }^{\text {Io }}$ and Washington ${ }^{\text {II }}$ gave their labor commissioners power to take assignments of wage claims, and sue in behalf of claimants who are without means. Massachusetts ${ }^{1_{2}}$ extended the coverage of their weekly payment laws to all employees; Maine, to restaurants. ${ }^{\mathrm{r}}$ New Hampshire applied its law to additional industries and strengthened enforcement sections. ${ }^{14}$ Colorado passed a law putting teeth in provisions safeguarding pay-rolls of mining companies. $^{x 5}$ California added to its successful law provisions for protecting the claims of seasonal workers. ${ }^{16}$ In 1936 a Louisiana law required wage payments within twenty-four hours to employees who resigned and made it a misdemeanor to employ a person with intent to defraud by failing to pay wages due. ${ }^{17}$ Eighteen states gave legislative attention to the problem this year and three states enacted comprehensive statutes. ${ }^{18}$

States which have considered the problem recently and which will do so in the future will be guided in the main by the recommendation of the

9 Ill. I. 1937,596 . In the short period since the law became effective more than 2300 applications have been filed with the Department of Labor and despite a limited staff more than $\$ 18,000$ has been collected.

${ }^{10}$ Mich. Pub. Acts I935, no. 224.

14 N.N.L. 1935, c. 69.

II Wash. L. I935, c. 96.

15 Colo. L. 1935 , c. $x 60$.

12 Mass. Acts and Resolves I935, c. 350.

${ }^{16}$ Calif. Stat. 1935 , c. 49 .

23 Maine L. I935, c. III.

${ }^{17} \mathrm{La}$. Acts $1936,563$.

${ }^{88}$ Language for State Wage Payment and Wage Collection Law (mimeographed) Bull. No. 463 of the Division of Labor Standards, U.S. Dept of Labor, Washington, D.C. (r937). 
International Association of Governmental Labor Officials adopted at the I936 annual convention and by the Third National Conference on Labor Legislation of last year. These recommendations have been advanced in the form of a draft prepared by a joint committee of both organizations. ${ }^{x 9}$ The standards suggested by the draft include: ( $\mathrm{I}$ ) payment of wages semimonthly on pay days and at places to be designated in advance by the employer; (2) payment of discharged workers within twenty-four hours, of workers who quit voluntarily within seventy-two hours, of striking employees at the next regular pay day; (3) concentration of responsibility in the labor commissioner with power to take assignment of wages and sue thereon in behalf of unpaid employees; (4) the imposition of a criminal penalty for failure to pay which may also be enforced by the labor commissioner; (5) power of inspection, of subpoenaing records, of administering oaths and examining witnesses. A unique recommendation is that making a general contractor responsible for the pay-rolls of the subcontractors. Undoubtedly many states will word their new statutes after the carefully considered language of the draft prepared by the joint committee.

There is one aspect of the problem of the collection of unpaid wages which in the opinion of the writer needs further thought and emphasis. Assuming a state adopts a law including all or most of the features recommended in the suggested draft, what effective remedy is available to an employee if when he comes for his pay his employer is devoid of resources with which to pay him? The only remedy, the criminal sanction, aside from its value as an inhibitory instrument, will not put money in the pocket of the unpaid worker. The worker, notwithstanding the law, may go without the necessaries of life. According to the National Industrial Conference Board ${ }^{20}$ the number of commercial failures in this country average I8,600 annually. Dun \& Bradstreet report, for the year I932, 31,822 failures with assets of approximately 500 million and liabilities double that amount; for I935, II,5 ro failures with assets of approximately $\$ 95,000,000$ and liabilities double that amount.

How many wage earners are affected by these failures we do not know, but it is reasonable to suppose that a large number are affected. The preference granted to wage claims under the National Bankruptcy Act is of little aid in a no asset case or where the assets are very small. This is brought home with great force when after months of waiting for the end of bankruptcy proceedings the client receives a check for sixty-

2 Illinois, New York and South Carolina, see note 6 supra.

${ }^{20}$ Nat. Ind. Conf. Board Bull. March ro, I936. 
three cents, or a like amount, his pro-rata share of the assets of the bankrupt. The I936 draft recognizes the problem to the extent that it made an employer liable for the pay-roll of a sub-contractor. But what of the many cases where no sub-contractor is involved? And further, what if the employer himself becomes financially insolvent? To remedy this the 1927 draft enables the commissioner of labor to require a bond of an employer after a judgment for unpaid wages is entered against him and upon his failure to post bond, to procure an injunction preventing him from continuing in business; and also provides for forfeiture of corporate charters for violation of the Act. These provisions have not, however, been followed in the drafting of legislation upon the subject, except in Colorado, Oregon, and New York. ${ }^{21}$

Other devices might be employed to overcome the financial vicissitudes of employers. Would it not be feasible to bond pay-rolls-that is, in the case of the employer of limited means, to require a bond with adequate security conditioned upon payment of all just wage claims? The I927 provision, requiring a bond of an employer after a judgment is rendered against him, operates after the fact-that is, it allows the employer one chance to default. The writer's proposal would not permit even this. The main difficulty with such a provision is that of working out the administrative details and overcoming constitutional obstacles-yet, if we have gone as far as to compel unemployment insurance on a national scale for workers who become idle as a result of economic circumstances, why not a similar type of insurance for the employee who has labored hard and long for his wages? The financial responsibility law of a number of states with reference to automobile owners at least suggests the possibility of requiring proof of financial ability to pay future claims for wages after a judgment has been entered against an employer and the judgment remains unsatisfied after the time for appeal expires. The right to do business as a corporation, joint-stock company or limited partnership might well be conditioned upon the payment of all just wage claims, and the liability for such wages might well rest on the shareholders, officers and directors of the corporation as well as upon the corporation. Finally, much might be

${ }_{21}$ Colo. L. I935, c. I60; Ore. L. I93 I, c. $287, \S 6$ (d) amended x933, c. 279 , § 3; N.Y.L. I937, c. 500, par, x. The Colorado statute although restricted to mining companies contains the most completely and carefully worded provisions as to financial responsibility. The recently enacted amendments to the California Law are of interest; Calif. Stat. I935, C.20o. Under them mining companies before starting operations must have on hand in cash or readily salable securities a sufficient amount to pay all employees. Failure to comply is a misdemeanor punishable by fine and imprisonment. 